DOI https://doi.org/10.30525/978-9934-588-79-2-2.42

\title{
СТЕНД ДЛЯ ВИПРОБУВАНЬ ЗАЛІЗНИЧНИХ КОЛІС НА КОНТАКТНУ МІЦНСТЬ
}

\author{
Ракша C. В. \\ доктор технічних наук, професор,
} завідувач кафедри прикладної механіки та матеріалознавства Дніпровського начіонального університету залізничного транспорту імені академіка Всеволода Лазаряна

Анофрієв П. Г.

кандидат технічних наук, дочент, кафедра прикладної механіки та матеріалознавства Дніпровського начіонального університету залізничного транспорту імені академіка Всеволода Лазаряна

Куроп'ятник О. С. кандидат технічних наук, доцент, кафедра прикладної механіки та матеріалознавства Дніпровського начіонального університету залізничного транспорту імені академіка Всеволода Лазаряна

м. Дніпро, Украӥна

Вступ. Однією із задач, які необхідно розв'язати з метою прогнозування ресурсу колісної пари (КП), є оцінка контактної міцності та зношення деталей КП, їх окремих поверхонь. Так у роботі [1] запропоновано стенд для проведення випробувань залізничних коліс на контактну міцність. Однак випробування $\epsilon$ імітаційними, тобто об'єктом досліджень є не залізничне колесо, а еквівалентний ролик.

Метою даної роботи є розробка схеми стенда для випробувань залізничних коліс на контактну міцність та встановлення залежності технічних параметрів стенда від експлуатаційних характеристик колісної пари, до складу якої входить випробовуване колесо.

\section{1. Загальний опис стенда}

Стенд моделює взаємодію залізничного колеса з рейкою під навантаженням, яке відповідає осьовому навантаженню колісної пари. Загальну схему стенда подано на рис. 1 .

Стенд складається з рами 3, на якій з можливістю обертання відносно власних осей та радіального переміщення відносно випробовуваного колеса 1 встановлено ролики 2, що перебувають у контакті 3 
випробовуваним колесом 1 під тиском, який створюється навантажувальним пристроєм 4. Випробовуване колесо 1 фіксується на осі 6 та разом із нею обертається за допомогою приводу стенда 5.

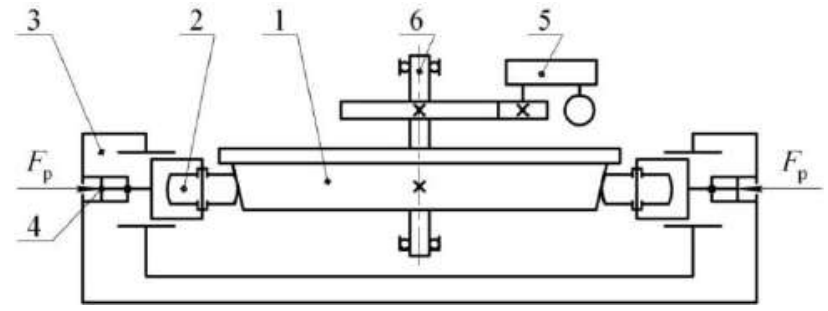

Рис. 1. Схема стенда:

1 - випробовуване колесо; 2 - ролик; 3 - рама; 4 - навантажувальний пристрій; 5 - привід стенда; 6 - вісь колеса $\left(F_{p}-\right.$ робоче зусилля стенда)

Вісь 6 може бути як віссю колісної пари (іï фрагментом), так i окремо виготовленою деталлю (технологічна вісь). Привід стенда 5 може мати довільну конфігурацію. Робоча поверхня ролика 2, що контактує 3 випробовуваним колесом 1 , повторює форму головки рейки у перерізі.

Випробовуване колесо обертається впродовж певного проміжку часу, який відповідає необхідному ресурсу колеса за контактною міцністю.

До технічних параметрів стенда відносимо робоче зусилля стенда, діаметр роликів, кількість роликів, частоту обертання випробовуваного колеса, тривалість випробувань.

\section{2. Обгрунтування технічних параметрів стенда}

У межах даної роботи встановлення залежності між окремими параметрами стенда та експлуатаційними характеристиками колісної пари здійснюється на основі положень механіки контактної взаємодії тіл криволінійної неузгодженої форми. Результати досліджень грунтуються на використанні теорії пружного контакту Герца [2].

Залізничне колесо та ролик стенда $є$ тілами неузгодженої форми із зовнішнім точковим контактом. Відносні радіуси кривизни кожного 3 тіл $\epsilon$ неоднаковими $\left(R_{1}^{\prime} \neq R_{1}^{\prime \prime} ; R_{2}^{\prime} \neq R_{2}^{\prime \prime}\right)$, тому внаслідок прикладання навантаження буде утворюватися ділянка контакту еліптичної форми. Це також стосується контактної взаємодії колеса із залізничною рейкою в реальних умовах експлуатації.

Відповідно до теорії пружного контакту Герца [2] для пар контакту «колесо-рейка» та «колесо-ролик» визначаємо такі величини: великий радіус кривизни $\left(R^{\prime}, r^{\prime}\right)$, малий радіус кривизни $\left(R^{\prime \prime}, r^{\prime \prime}\right)$, еквіва174 
лентний радіус кривизни $\left(R_{\mathrm{e}}, r_{\mathrm{e}}\right)$ та максимальний контактний тиск $\left(p_{0}\right)$. У цих записах великими літерами позначено величини, які характеризують пару «колесо-рейка» в реальних умовах експлуатації, а малими літерами - величини, які характеризують пару «колесоролик» на стенді. Максимальний контактний тиск надалі буде прийнято однаковим для обох пар.

За результатами досліджень для пари «колесо-рейка» отримано залежності:

$$
\begin{gathered}
R^{\prime}=\left(\frac{1}{R_{1}^{\prime}}+\frac{1}{R_{2}^{\prime}}\right)^{-1}=R_{1}^{\prime} ; \quad R^{\prime \prime}=\left(\frac{1}{R_{1}^{\prime \prime}}+\frac{1}{R_{2}^{\prime \prime}}\right)^{-1}=R_{2}^{\prime \prime} ; \quad R_{\mathrm{e}}=\sqrt{R^{\prime} R^{\prime \prime}}=\sqrt{R_{1}^{\prime} R_{2}^{\prime \prime}} ; \\
p_{0}=\left(\frac{6 P E * E^{* 2}}{\pi^{3} R_{\mathrm{e}}^{2}}\right)^{1 / 3} \times\left[F_{1}\left(R^{\prime} / R^{\prime \prime}\right)\right]^{-2 / 3} .
\end{gathered}
$$

У формулі (1) прийнято позначення: $P$ - нормальна сила в зоні контакту - складова навантаження в зоні контакту, яка діє уздовж спільної нормалі до контактуючих поверхонь у точці контакту; $F_{1}\left(R^{\prime} / R^{\prime \prime}\right)-$ коефіцієнт, який враховує ексцентриситет фактичної поверхні контакту тіл (еліпсу), він $є$ функцією відношення великого та малого відносних радіусів кривизни, може бути визначений за рекомендаціями [2]; $E^{*}$ - приведений модуль пружності [2].

Нормальна сила в зоні контакту

$$
P=0,5 F \cos \beta,
$$

де $F$ - осьове навантаження колісної пари; $\beta$ - ухил поверхні катання колеса (кут $\beta$ відповідає конусності 1:10, що вказана у ГОСТ 10791).

Контактна взаємодія елементів пари «колесо-ролик» характеризується такими параметрами:

$$
\begin{gathered}
r^{\prime}=\left(\frac{1}{R_{1}^{\prime}}+\frac{1}{r_{2}^{\prime}}\right)^{-1} ; \quad r^{\prime \prime}=\left(\frac{1}{R_{1}^{\prime \prime}}+\frac{1}{r_{2}^{\prime \prime}}\right)^{-1}=R_{2}^{\prime \prime} ; \quad r_{\mathrm{e}}=\sqrt{r^{\prime} r^{\prime \prime}}=\sqrt{R_{2}^{\prime \prime} \cdot\left(\frac{1}{R_{1}^{\prime}}+\frac{1}{r_{2}^{\prime}}\right)^{-1}} ; \\
p_{0}=\left(\frac{6 P_{\mathrm{c}} E^{* 2}}{\pi^{3} r_{\mathrm{e}}^{2}}\right)^{1 / 3} \times\left[F_{1}\left(r^{\prime} / r^{\prime \prime}\right)\right]^{-2 / 3} .
\end{gathered}
$$

У формулі (3) нормальна сила в зоні контакту «колесо-ролик»

$$
P_{\mathrm{c}}=F_{\mathrm{p}} \cos \beta,
$$

де $F_{\mathrm{p}}$ - робоче зусилля стенда - сила, яку прикладає навантажувальний пристрій до ролика (див. рис. 1). 
Для забезпечення відповідності умов стендових випробувань реальним умовам експлуатації колісної пари необхідно, щоб максимальний контактний тиск у парі «колесо-ролик» на стенді дорівнював максимальному контактному тиску в парі «колесо-рейка» в реальних умовах експлуатації. Прирівнюючи праві частини рівнянь (1) та (3), отримуємо:

$$
\left(\frac{6 P E^{* 2}}{\pi^{3} R_{\mathrm{e}}^{2}}\right)^{1 / 3} \times\left[F_{1}\left(R^{\prime} / R^{\prime \prime}\right)\right]^{-2 / 3}=\left(\frac{6 P_{\mathrm{c}} E^{* 2}}{\pi^{3} r_{\mathrm{e}}^{2}}\right)^{1 / 3} \times\left[F_{1}\left(r^{\prime} / r^{\prime \prime}\right)\right]^{-2 / 3} .
$$

В роботі [2] відмічено, що у першому наближенні функції $F_{1}$ можна прийняти рівними одиниці. Тому після виконання математичних перетворень маємо:

$$
\frac{P}{P_{\mathrm{c}}}=1+\frac{R_{1}^{\prime}}{r_{2}^{\prime}} \Rightarrow P_{\mathrm{c}}\left(r_{2}^{\prime}\right)=P \cdot\left(1+\frac{R_{1}^{\prime}}{r_{2}^{\prime}}\right)^{-1} .
$$

Аналіз залежності $P_{\text {c }}\left(r_{2}^{\prime}\right)$ показав, що вибір роликів меншого діаметра (радіус ролика $r_{2}^{\prime}$ ) дозволяє зменшити силу $P_{c}$, а отже, й робоче зусилля стенда.

Відмічаємо, що стенд може бути універсальним: отримана залежність (5) у поєднанні з формулами (2) та (4) дозволяє визначати робоче зусилля стенда для різних осьових навантажень колісної пари, в тому числі за умови незмінного діаметра роликів, а можливість переміщення роликів у радіальному напрямку по відношенню до колеса дозволяє випробовувати колеса різних діаметрів.

Тривалість випробувань коліс $(T)$ на стенді залежить від кількох факторів: необхідний ресурс коліс за контактною міцністю в кілометpax $\left(L_{\mathrm{k}}\right)$; кількість роликів $(k)$; частота обертання колеса в обертах за хвилину $(n)$. Ці величини пов'язані між собою:

$$
T=\frac{60 L_{\mathrm{k}} \cdot 10^{3}}{\pi n D_{\mathrm{k}} k} .
$$

Отримана залежність дозволяє встановлювати значення частоти обертання колеса та кількості роликів для отримання прийнятної тривалості випробувань з урахуванням необхідного ресурсу коліс (колісної пари).

Висновки.

1. Розроблено схему стенда, який дозволяє проводити випробування залізничних коліс на контактну міцність. 
2. На основі положень механіки контактної взаємодії, зокрема, теорії пружного контакту Герца, встановлено залежності величин діаметра роликів та робочого зусилля стенда від експлуатаційних характеристик колісної пари, до складу якої входить випробовуване колесо. Доведено взаємний вплив цих величин.

3. Встановлено функціональну залежність, яка пов'язує між собою тривалість випробувань, частоту обертання випробовуваного колеса та кількість роликів; вона також визначає вплив характеристик колісної пари на ці величини.

\title{
Література:
}

1. Воробьев А. А. Прогнозирование ресурса и совершенствование технологии ремонта колес железнодорожного подвижного состава: автореферат дис. ... доктора техн. наук, 05.22.07 - подвижной состав железных дорог, тяга поездов и электрификация. 2018. 36 с.

2. Джонсон К. Механика контактного взаимодействия: пер. с англ. Москва, 1989. 510 с.

DOI https://doi.org/10.30525/978-9934-588-79-2-2.43

\section{ДОЦІЛЬНІСТЬ ВИКОРИСТАННЯ ДИЗЕЛЬНОГО БІОПАЛИВА МІСЬКИМИ АВТОБУСАМИ}

\author{
Сімоненко В. В. \\ кандидат технічних наук, \\ дочент кафедри дорожніх машин \\ Національного транспортного університету \\ м. Київ, Украӥна
}

В теперішній час основна частина моторних палив виготовляється 3 корисних копалин, в основному, з нафти. Серед різних видів транспорту іiі частка особливо велика в автотранспорті, на потреби якого витрачається більше $50 \%$ від загальної кількості видобутої сировини. Серед усіх видів наземного та водного транспорту близько $64 \%$ моторних палив, що витрачаються, припадає на легкові та вантажні автомобілі, а також автобуси (до 18\%) [1].

Особливе місце серед двигунів внутрішнього згоряння (ДВ3) посідають дизелі, які встановлюються на переважній більшості сільськогосподарських, дорожньо-будівельних машин. Найближчим часом вони збережуть широке використання на автомобільному транспорті, 